Mitteilungen der Österreichischen Geographischen Gesellschaft, 160. Jg., S. 263-279

(Annals of the Austrian Geographical Society, Vol. 160, pp. 263-279)

Wien (Vienna) 2018, https://doi.org/10.1553/moegg160s263

\title{
Place-name Policies in Scandinavia AND ELSEWHERE ${ }^{1)}$
}

\author{
Staffan NYSTRÖM, Uppsala (Sweden)* \\ Initial submission / erste Einreichung: 09/2017; revised submission / revidierte Fassung: 10/2018; \\ final acceptance / endgültige Annahme: 12/2018 \\ with 2 figures and 1 table in the text
}

\section{CONTENTS}

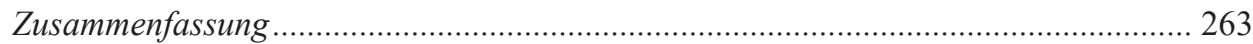

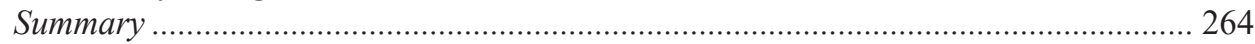

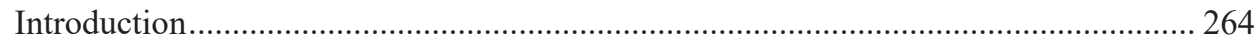

1 What does a place-name policy involve and why is it needed? ............................. 265

2 Who has the right to draw up a place-name policy? ............................................... 266

3 Who and what is affected by a place-name policy? ............................................. 269

4 What can an official place-name policy include? ................................................. 272

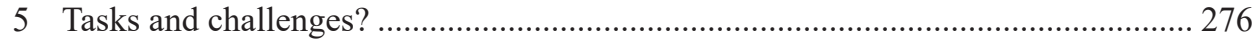

6 What contributions can place-name researchers make? ......................................... 277

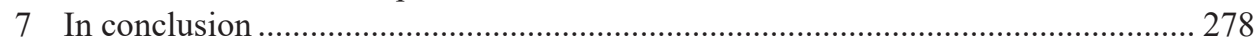

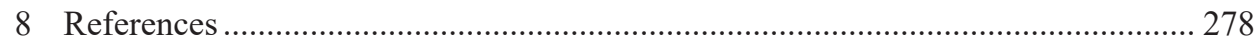

\section{Zusammenfassung}

\section{ORTSNAMENPOLITIK IN SKANDINAVIEN UND DARÜBER HINAUS}

Die gewählte Ortsnamenpolitik (oder das Fehlen einer solchen) kann den Bestand an Ortsnamen wie auch neu aufkommende, vorgeschlagene oder künftige Ortsnamen auf unterschiedliche Weise beeinflussen. Sie kann Regeln der Benennung, der Erhaltung von Namen, der Namen-Gesetzgebung und der Namenplanung umfassen, das heißt, alle Schritte von Beobachtungen und Ideen bis zur Entscheidung, und Einzelne oder Gruppen genauso beeinflussen wie wichtige Sozialstrukturen und Funktionen. Was sind also die

1) The paper is based on the authors' plenary paper given at the XXVI International Congress of Onomastic Sciences in Debrecen, Hungary, 2017. The first version of this paper was published in one of the volumes including the papers presented at the congress (Onomastica Uralica 14, Debrecen, 2018).

* Prof. Dr. Staffan Nyström, Department of Scandinavian Languages, Uppsala University, Sweden. Address: Scandinavian Onomastics, Box 135, SE-751 04 Uppsala, Sweden; email: staffan.nystrom@nordiska.uu.se 
Hauptaufgaben und Herausforderungen heutiger Ortsnamenpolitik in Skandinavien und darüber hinaus? Wie können heutige Anforderungen und wie kann der aktuelle Gebrauch mit der Forderung vereinbart werden, Ortsnamen als Teil unseres immateriellen kulturellen Erbes zu schützen? Und schließlich: Wie können Onomastik und Onomastiker am besten helfen und zu Verständnis und Bewusstsein dieser wichtigen Aspekte von Namen und Namengebung beitragen? In diesem Artikel werden diese Fragen (vor allem mit Beispielen aus Schweden) diskutiert - natürlich ohne definitive Antworten oder Lösungen zu bieten.

Schlagwörter: Familiennamen, Doppelbenennungen, Onomastik, Ortsnamenbehörde, Ortsnamen-Gesetzgebung, Ortsnamenplanung, Ortsnamenpolitik, Ortsnamenregulierung, Straßennamen, Toponymie

\section{Summary}

A chosen place-name policy (or the lack of such a policy) might affect the existing place-name stock as well as emerging, proposed or future place-names in many ways. A chosen place-name policy might include name regulation, name preservation, name legislation, and name planning - including every step from observations and ideas to decision-making. It might affect individuals or groups of people as well as important societal structures and functions. So, what are the main tasks and challenges of today's place-name policies in Scandinavia and elsewhere? How can modern demands and modern usage be combined with a quest to safe-guard place-names as part of our intangible cultural heritage? And finally, how can onomastics and onomasticians help the most and contribute to the understanding and awareness of these important aspects of names and naming. - In this paper I discuss these matters (with examples mostly from Sweden) - of course without giving any definite answers or solutions.

Keywords: Block name, dual naming, onomastics, place-name authority, place-name legislation, place-name planning, place-name policy, place-name regulation, street name, toponymy

\section{Introduction}

When I was asked by the congress organisers in Debrecen to talk about "name policy in $21^{\text {st }}$ century society" my first thought was to make a more direct comparison of different countries and provide examples of strategies, regulations, differences and similarities. But there turned out to be no point in doing so! There are hordes of variations, of linguistic and pragmatic conditions, of different problems and solutions so that I soon abandoned the idea. Instead I will focus on place-name policy principles from a more overall perspective based to some extent on examples from Scandinavia and Sweden in particular. Even so I hope that many readers will identify with my discussion and that what I say can be applied in different circumstances and situations in different parts of the world. 


\section{What does a place-name policy involve and why is it needed?}

What does a place-name policy involve? In my opinion it means that approaches or courses of action are based on principles - regulations, strategies or agreements of some sort - about how place-name issues can, in broad terms, be "managed". Principles of this kind are as a rule intentional but they can be created or applied more or less unconsciously. The principles can be determined in due political or judicial processes or merely be implicit, and they can be codified in writing or based on custom and usage. The principles may be generally applicable or linked to specific contexts, situations, stakeholders or types of names and, like all policies, a place-name policy may be popular and enjoy respect or quite the opposite.

There are many reasons why a place-name policy is needed today, and these include the following. Earlier most of the repertoire of place-names developed spontaneously in everyday contacts between individuals and they were shaped by their users themselves. Anything that needed a name was given one and the names were mainly used orally. If a name was, nevertheless, written down, it could admittedly vary a great deal in both form and spelling but the main thing was that it functioned, that it served its purpose in identifying a specific locality. In the local context in which a name was used there was a natural process of elimination so that collisions (in other words the use of identical or almost identical names for localities close to each other) were avoided and other linguistically inappropriate names (too long, too difficult to pronounce) removed. Practical everyday needs led automatically to a certain extent of pruning of the way names were used to make life easier for the individual users.

In modern contexts as well, especially in urban settings, place-names would probably more often be created ad hoc with little systematisation if there were no place-name policies at all. There would probably be a much larger number of contributors to the placename market. Less consideration would be paid to the possibilities of confusion and to the way new names could integrate with and adapt to the current repertoire of names. New names could more easily be created on the basis of the opinions and preferences of powerful individuals or groups. Names that aroused the displeasure of some could be discarded and replaced by new ones in a very subjective way. Commercial interests could shape and influence the repertoire of names, economic arguments could easily gain a hearing, and contradictory trends and models could develop alongside each other. Without an overall place-name policy, there would be a risk that both new and existing names could be formed and developed totally in accordance with prevailing usage, so that varied and competitive pronunciation and morphology would be allowed to emerge. There would be no policy that could monitor and moderate the repertoire of names to make it possible to regulate and coordinate their use.

Today sets of place-name users - in other words the groups of individuals that know and use the same names - look different from those of the past. Our urban environments in particular are larger and more complex than they used to be. Because of new technology, modern communications and totally different media, place-names, the way in which they are used and new proposals reach large groups of people very quickly, while at the same time the self-regulation of the repertoire of names that characterised earlier and less open local communities no longer functions as it did. Opinions, ideas and initiatives 
- even where place-names are concerned - can circulate widely at lightning speed irrespective of their quality. This is why a deliberate place-name policy is needed, one that provides a sound overview and some control of both individual names and the repertoire of place-names as a whole, a policy that forestalls personal preferences, drastic and arbitrary changes in the place-name repertoire, and confusing and capricious variation in their morphology and spelling. In most parts of the world, most of the repertoire of official names result from official decisions of one kind or another. Here there is a process, an idea, an intention - in other words names are based on certain principles. A place-name policy with explicit principles makes life easier for those who decide on names (officials and politicians) as well as for individuals or sets of users (the general public).

When we talk about principles and place-name policies of this kind, it is more than likely that we most frequently envisage official policies that are applied by government and municipal bodies - even though these applications may take very different forms of organisational expression in different cities, provinces and countries. But to establish and maintain a place-name policy all that is really needed is access to some type of place-name - a group of names or a naming system - as well as a mandate of some kind to control and influence these names. This can involve certain categories of names, for instance street names in a city, a farmer's fields, states that form a nation, lighthouses along a coastline, nature reserves in a province or something entirely different. A place-name policy may have the power to impose sanctions to some extent and the decision-makers are appointed in different ways or even nominate themselves. Some place-name policies apply to official names, like for instance the names of municipalities, railway stations or real estate, and decisions about them are made pursuant to legislation or ordinances by a specific authority, group or individual empowered to do so. Other types of name are less official but even so may be subject to a place-name policy based on traditional usage or according to recently established "rights" for which there is no explicit support in the legislation or statutes. If varying place-name policies of this kind come into conflict with each other, in most cases those that have been established through due political or legal process should be given greatest weight. In practice, for instance, a local usage or local customs may conflict with the national policy enforced by a government authority with the force of law. Ultimately it is the authority that is legally entitled to decide. Even so, this can give rise to disputes.

What is needed, therefore, to implement a specific place-name policy is no more than a strong will and a number of names that can be subjected to it. But to implement a rational place-name policy, knowledge is also needed, as well as an overall perspective and a capacity to listen. And in addition the implementation of a rational and legally grounded (official) place-name policy requires an acknowledged right (codified in legally valid provisions or according to generally accepted usage) to deal with and make decisions about a certain category of names.

\section{Who has the right to draw up a place-name policy?}

So who has this right? Here things look very different in different parts of the world. Differences already appear when you compare the Scandinavian countries with each other. 
To begin with, we can also determine that there are international organisations, groups and corporations that may have opinions about names, such as Google (through Google Maps), the ICA (International Cartographic Association), the IGU (International Geographical Union), IHO (International Hydrographic Organisation), ICOS (International Council of Onomastic Sciences), and UNGEGN (United Nations Group of Experts on Geographical Names), but this does not mean that any of these organisations has the right to decide on individual names or naming that outweighs stakeholders at the national level. They can give advice and recommendations or adopt resolutions but it is still up to each nation itself to decide on place-name policies within its own boundaries.

One of the early resolutions adopted in the work of the UN (1/4 from 1967) ${ }^{2}$ stated therefore that each country should have a national place-name authority of some kind to take overall responsibility for all forms of place-names that are not explicitly assigned to some other domain. The wording of the resolution states, for instance that:

"It is recommended that, as a first step in international standardization of geographical names, each country should have a national geographical names authority. [...] It is recommended that those countries which have not yet begun to exercise their prerogative of standardizing their geographical names on a national basis should now proceed to do so."

A great deal has happened since then but some countries still lack this kind of authority with overall responsibility for place-names.

Issue 51 of UNGEGN's Information Bulletin ${ }^{3)}$ from November 2016 was entirely devoted to "National Names Authorities - structures and operations". It offers concise descriptions of how a dozen countries have organised their official place-name operations and these examples alone show how they can differ. The first page of the bulletin includes a map that shows which countries today have national place-name authorities and which that do not. The map on the next page (Fig. 1) shows exactly the same thing. We can see for instance that Finland, the Netherlands and the United Kingdom lack authorities of this kind. Of course this does not mean that there is a place-naming anarchy in these countries, but they have so far chosen other solutions.

When it then comes to the rules and treatment of different kinds of names and of objects to which names are given, each country has its own solutions that more or less correspond with each other. In the publication entitled God ortnamnssed [Good placename practice] published by the Swedish Place-Name Advisory Board [Ortnamnsrådet] in 2016 there is a table listing official decision-makers in Sweden. This table shows clearly who is entitled to decide on which names and on what grounds, as well as who has to be consulted before a decision is made, for instance. A small part of the table is shown below (Table 1). I should point out here that Lantmäteriet is the Swedish Mapping, Cadastral and Real Estate Authority:

\footnotetext{
2) All UN resolutions on names can be found through UNCSGN Resolutions Database Search on $h t t p: / / w w w$. ngii.go.kr/portal/ungn/mainEn.do.

3) Bulletins (started in 2003) and newsletters (1988-2002) can be found on https://unstats.un.org/unsd/geoinfo/ UNGEGN/bulletin.html.
} 


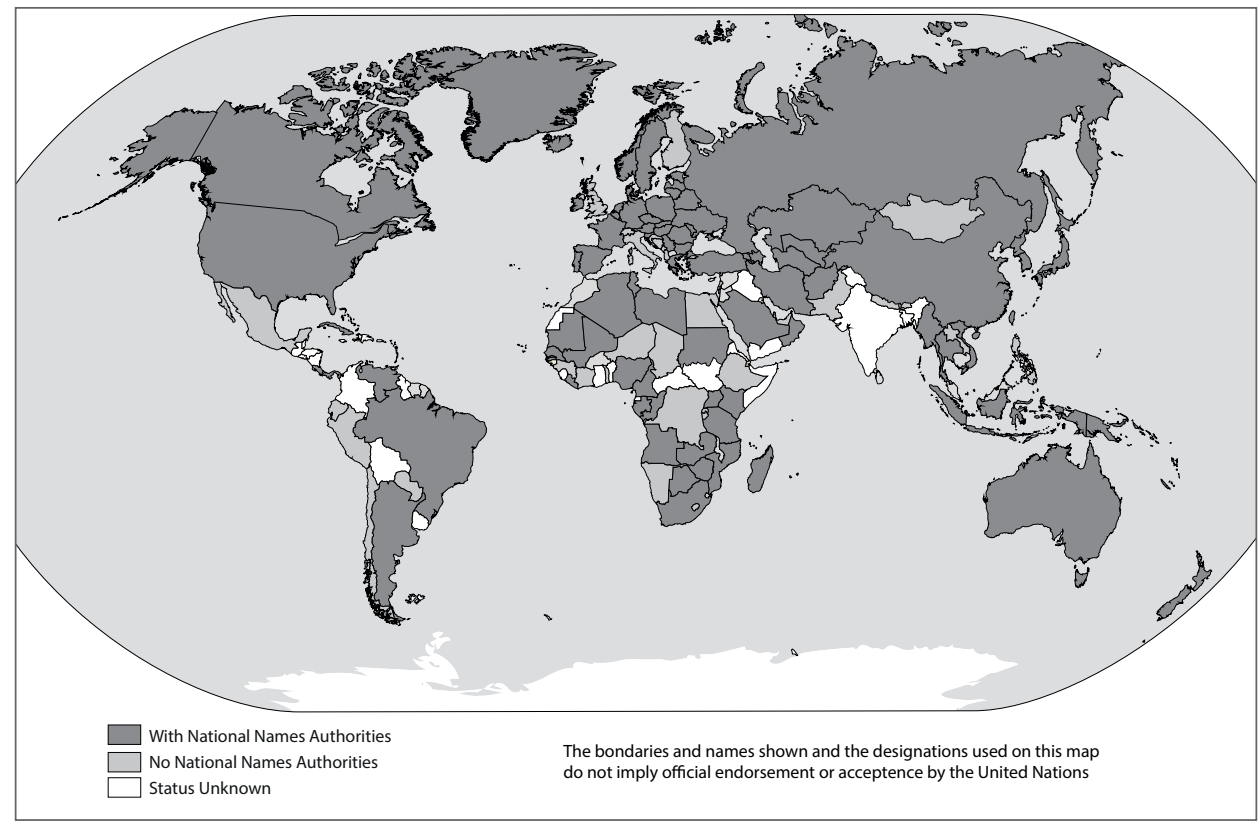

Source: UNGEGN Information Bulletin 51, 2016, p. 1

Figure 1: Geographical Names Authorities (July 2016)

\begin{tabular}{|c|c|c|c|}
\hline Object & $\begin{array}{c}\text { Consultant/ } \\
\text { Advisory Bodies }\end{array}$ & Decision made by & Statutory support \\
\hline Counties & $\begin{array}{l}\text { Lantmäteriet and the } \\
\text { Institute for Language } \\
\text { and Folklore, accord- } \\
\text { ing to precedent }\end{array}$ & $\begin{array}{l}\text { Government drafts, } \\
\text { Parliament decides }\end{array}$ & $\begin{array}{l}\text { Decree on the Names } \\
\text { of Counties }(1973, p \text {. } \\
105) \text {. }\end{array}$ \\
\hline Municipalities & $\begin{array}{l}\text { Lantmäteriet and the } \\
\text { Institute for Language } \\
\text { and Folklore, accord- } \\
\text { ing to precedent }\end{array}$ & $\begin{array}{l}\text { Swedish Legal, Fi- } \\
\text { nancial and Adminis- } \\
\text { trative Services Agen- } \\
\text { cy drafts, Government } \\
\text { decides }\end{array}$ & $\begin{array}{l}\text { Act on Changes in the } \\
\text { Division of Sweden } \\
\text { into Municipalities } \\
\text { and County Councils, } \\
\text { Section 1:1 (1979, p. } \\
\text { 411). }\end{array}$ \\
\hline Districts & $\begin{array}{l}\text { Lantmäteriet and the } \\
\text { Institute for Language } \\
\text { and Folklore, accord- } \\
\text { ing to precedent }\end{array}$ & Government decides & $\begin{array}{l}\text { Ordinance on Dis- } \\
\text { tricts }(2015, \text { p. } 493) .\end{array}$ \\
\hline $\begin{array}{l}\text { City blocks (in the } \\
\text { cadaster of real estate) }\end{array}$ & Lantmäteriet & Municipalities & $\begin{array}{l}\text { Ordinance on the } \\
\text { Real Estate Cadaster } \\
\text { (2000, p. 308). }\end{array}$ \\
\hline
\end{tabular}




\begin{tabular}{|l|l|l|l|}
\hline \multicolumn{1}{|c|}{ Object } & \multicolumn{1}{|c|}{$\begin{array}{c}\text { Consultant/ } \\
\text { Advisory Bodies }\end{array}$} & \multicolumn{1}{|c|}{ Decision made by } & \multicolumn{1}{|c|}{ Statutory support } \\
\hline Dioceses & The General Synod & $\begin{array}{l}\text { Swedish Church } \\
\text { Ordinance. }\end{array}$ \\
\hline Natural features & $\begin{array}{l}\text { The Institute for Lan- } \\
\text { guage and Folklore }\end{array}$ & Lantmäteriet & $\begin{array}{l}\text { Ordinance with } \\
\text { Instructions for Lant- } \\
\text { mäteriet Section 5:7 } \\
\text { (2009, p. 946). }\end{array}$ \\
\hline $\begin{array}{l}\text { Streets, roads, public } \\
\text { places in detailed } \\
\text { development plans }\end{array}$ & $\begin{array}{l}\text { Lantmäteriet with the } \\
\text { support of the Insti- } \\
\text { tute for Language and } \\
\text { Folklore if needed }\end{array}$ & Municipalities & No legal provision. \\
\hline
\end{tabular}

Source: Ortnamnsrådet (Swedish Place-Name Advisory Board): God ortnamnssed (Good placename practice), 2016, excerpt

Table 1: Institutions and authorities enabled to decide on place-names in Sweden

Tables of this kind can be made for every country to provide surveys and enable comparisons. This would offer both quantitative and qualitative insights about which objects different countries decide on, at what level these decisions are made, who decides, how many stakeholders are involved, to what extent legislation and regulations exist, etc. The issue of official dual or multiple naming of geographical features will be briefly discussed below. These tables could also give rise to ideas, proposals and procedural models that we could all consider. The task of gathering all the necessary information and collating it systematically is a gigantic one, but someone may be prepared to undertake it in the future - perhaps a working group in UNGEGN.

\section{Who and what is affected by a place-name policy?}

What then can we manage with a specific place-name policy and what is not affected? To begin with, we can wonder about who it will affect. Who do its contents, proposals and decisions concern? In principle, of course, a place-name policy can be very far-reaching and apply stringently to the use of all place-names. In Sweden the paragraph on good place-name practice in the "Historic Environment Act" applies explicitly only to state and municipal activities, i.e. public agencies and the like. Officials and politicians who deal with and decide on place-names must comply with the letter and spirit of the law to the best of their abilities. The users, in other words the rest of the population, have to accept and live with their decisions. But when it comes to non-governmental and non-municipal bodies this legal provision does not apply. In theory private companies, shops, publishers, newspapers and individuals may spell place-names any way they want to and even create their own names, registers, databases and maps that have no official status. Leaving aside the confusion and variations in names that fail to serve their purpose that this could give rise to, it is nevertheless completely possible. 
Unofficial place-naming may therefore end up conflicting directly with an official placename policy like Sweden's.

There may be those who do not agree with the existing official place-name policy (either national or municipal). A group, an individual or an organisation may prefer one or more alternative names to the one officially adopted because the names they advocate serve their purpose better, for instance by presenting something in a more positive light or by toning down or concealing something, perhaps a name that is alleged to have a bad ring to it. A more commercial name, sometimes called an "estate agent's name", may then be proposed either by creating something totally new that arouses positive associations or by extending the use of an existing name with a positive aura.

In the context of the catastrophic fire at Grenfell Tower in London at the beginning of the summer 2017 there were discussions about a suitable name for the area in which it stood. It is normally referred to by its address - Latimer Road - but recently it has more often been called North Kensington, even though it has few links with the "real" Kensington further south. But the prestige and reputation of the name Kensington can be "borrowed" to raise the status of an area that is looked down on.

This kind of unofficial, manipulative use of names is something we recognise from many parts of the world and it is difficult, if not to say impossible, to eradicate on the grounds of an official place-name policy, whether it has the force of law or not. One cannot in spite of everything disregard the fact that place-names have many different functions and that their fundamental - cognitive - purpose of identifying and specifying a certain location is sometimes eclipsed by other functions such as emotional and idealistic ones. Here names become something more than tools for identification and for finding our way around: they function symbolically, embody intentions, are weapons in public and political debates, express opinions, preferences and feelings as well as social bonds. When functions like these prevail, a stringent place-name policy will not always be enough to keep deviations and exaggerations at bay.

The same applies to slang terms and different affectionate forms of official names that are probably always going to arise because of human linguistic playfulness and efforts to simplify language. Place-names that are too long or too pretentious risk being morphed into more everyday, more manageable, perhaps temporary forms. In my opinion it is impossible to prevent this with an official place-name policy and there is probably little point in doing so, either. Then the names should have their official forms in more official (written) contexts and their unofficial form may be used elsewhere.

Here it is also worth recalling policies that actively attempt to make use of the popular, unofficial names and types of names that are in use. These occur in spoken everyday speech, irrespective of whether they are condoned officially or not. Trials have been carried out in Sweden, in the city of Gävle for instance, in which Lantmäteriet used a special telephone app to collect previously unrecorded, popular place-names used in this urban area. The results have been presented in several articles (e.g. ToRENsJö 2015). It is possible to have a deliberate policy of collecting unofficial names and recording them on special maps or in special databases so that the police and emergency services, for instance, can identify all the locations in the city by both their popular and official names. This does not mean that the names are approved and given official status, but 
they can still be accepted as a natural element of place-names usage and can be of great practical use. In addition, names like these can provide a basis for scholarly studies of the linguistic landscape and for place-name studies with a socio-onomastic and folk onomastic approach.

Choosing a place-name policy can influence and affect individuals or groups of people, as well as general social functions and structures. Names that have a public function concern everyone in some sense while those of a more private nature impact on fewer individuals. Which is perhaps not so odd. In purely principle terms, of course, although once decided a place-name policy applies to the same extent to all the names it concerns, it is undeniably the case that these policies are considered to be more important when they apply to names that are used frequently - in other words often, by many users and in many different contexts - than those that concern names used rarely and in special contexts.

One simple illustration of this can be found in the names given to blocks and streets in Sweden. Figure 2 shows a local plan from Stockholm indicating where new names are needed. City blocks have to have names in Stockholm but they primarily serve a technical purpose. They are used in land registries and appear in certain official situations, such as the real estate cadaster, conveyancing etc., but are not often used in everyday speech. The exception is when these block names take on a secondary function as the names of shopping malls, for instance, sheltered housing or pre-schools. The names used more often for

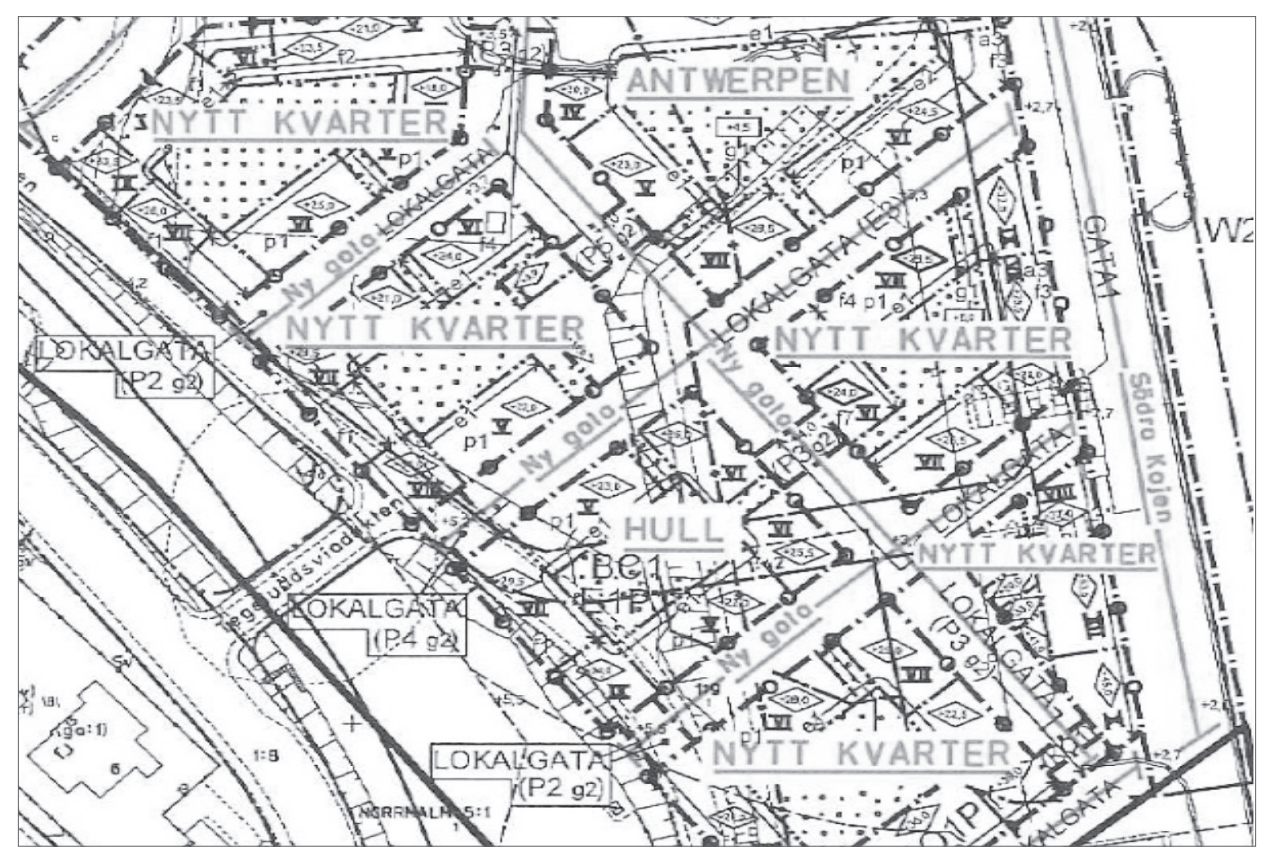

Figure 2: Detail of a local plan from Stockholm, showing where new names are needed. Nytt kvarter $=$ new block, ny gata $=$ new street. Already existing block names are Antwerpen and Hull 
everyday purposes, on road signs, in addresses and GPS navigators, and for giving directions are, after all, street names. This means that we could consider that greater demands are made of street names and a prudent place-name policy is necessary. The general guidelines for new names - which are often stressed in Sweden - say that names must be easy to grasp, to pronounce, to spell and to remember, and these demands are more applicable to streets than to city blocks.

This can provide the background for discussion of what are called commemorative names, place-names that include the name of an individual and which are intended to honour or remind us in some other way of a specific person (NYSTRÖm 2013). It might well be better to avoid long commemorative names or those that are difficult to spell or only give them to objects whose names do not need to be written down so often. Because what can happen? Well in Stockholm, for example, the name Johan Helmich Romans Park is not used by the general public as it is very long, difficult to spell and the man himself is not at all well known today. On the other hand Dag Hammarskjölds väg in Uppsala is admittedly used fairly frequently and denotes a well-known person but even so it gives rise to the colloquial variant $\operatorname{Dag} H$, which is sometimes used for convenience as the real name is a little too long. In a place-name policy that involves commemorative names one could opt to include - in addition to the requirement that the individual concerned is dead and has been for some period of time - the principle that commemorative names normally should not be created that are considered likely to cause difficulties for users because of their spelling or pronunciation. A waiting period after the death of an individual can be one year, five or twenty-five years, or some other period of time. In the UN resolution (VIII/2) adopted in 2002 no actual time period is specified. The recommendation merely states that "the appropriate national authorities include in their guidelines clear statements on the length of the waiting period they wish to establish before using a commemorative name".

\section{What can an official place-name policy include?}

A place-name policy can include for instance 1) place-name planning, 2) placename regulation, 3) place-name preservation and 4) place-name legislation and include everything from observations and ideas to discussions, drafting and decision making. At times the different elements merge into each other and often take place in parallel.

\subsection{Place-name planning}

Let me begin with place-name planning. Here a policy may entail listening to and involving either very few participants or a large number. In addition to the organ making the decision (political or technical) a special drafting body can be set up. Stakeholders in the form of property owners and other users of names, like residents in a street, village, town or whatever, can also be involved. The drafting bodies, for instance place-name drafting groups or urban place-name committees can consist solely of politicians who 
submit their own proposed names, discuss them and reach decisions, but they may also be groups with special expertise that produce proposals to submit to the politicians who decide. An adopted place-name policy can here, to put it simply, involve as many people as possible in the planning process - which makes it highly democratic but at the same time more extensive, costly, slower and more cumbersome - or for the sake of convenience and efficiency the planning can be restricted to a smaller group of place-name "professionals".

\subsection{Place-name regulation}

I use the term place-name regulation to refer to the management and control of the external features of existing and planned names, their morphology and spelling. Here a policy can apply different principles: as in Sweden where it is generally provided in the legislation that place-names must comply with acknowledged rules for linguistic correctness. This means that the rules and norms that apply to the spelling and morphology of the language in general (codified in the Swedish Academy's lexicon) also apply to placenames as far as possible. Exceptions can be made when deviant forms of names were established a long time ago and have then been used in every context. In such cases names are not altered to comply with the main rule.

This policy means that the national, shared written language also characterises and governs the use of place-names. Local, dialect or idiosyncratic pronunciation and spelling variants are not allowed to have any impact on the official written forms. Anyone may pronounce place-names as they want to, but everybody writes them in the same way. The generic element -vägen 'road, street' can for instance be pronounced as /vä:gen/, /ve:gen/, /ve:gön/, /we:n/, /vejen/ etc. But all over Sweden its written form is -vägen. This means that local and private perspectives sometimes collide with the overriding national rules. Then people may feel that the state, the authority or some other superior agency is making decisions about their names and that their genuine language and their genuine names are being suppressed and forbidden. This is true, and one can have different opinions about this fact. But a shared national standardised written form undeniably makes it easier to search for names or addresses in a register, GPS or some other database.

It is also possible to allow the inherited, local pronunciation to play a greater role when it comes to writing a name, as in the Norwegian place-name law. ${ }^{4)}$ In it Section 4 lays down that:

"Where nothing else is provided in this Act, the written forms of place-names are to be determined on the basis of the inherited local pronunciation." And later: "When the same name is used for different objects in one and the same locality, the written form used for the object the name originally referred to shall, as a rule, provide guidance on the written forms to be used for the other objects it identifies. [...] Two or more written forms of the same name for the same object can be determined as parallel if one or more of the following criteria are satisfied:

4) https://lovdata.no/dokument/NL/lov/1990-05-18-11. 
a. There are several variant pronunciations of the name because the locality covers a wide geographical area or is situated on the border of a dialect or administrative area.

b. Two or more written forms of the name are well established.

c. There is powerful local interest in two or more forms."

This of course leaves an opening for greater variation in writing when the elements in names with the same etymology can appear differently in maps or road signs for instance.

Denmark's place-name policy is described as follows by Peder GAMMELTOFT in the UNGEGN Bulletin from 2016 referred to above:

"In Denmark the Place-Name Commission (which is the standardising body) maintains a website of approximately 25,000 authorised names. The names included in the lists of authorised names represent only a small part of Danish place-names, as it includes only the names for which there is a practical (cartographic, postal, local, etc.) need of a uniform spelling. This means first and foremost that all major and minor settlements of importance to state affairs must have an authorised form. [...] In addition to this the Place-Name Commission has published a recommendation on their website to use Danish Orthography."

So - the external form of place-names (spelling and morphology) can be regulated in a number of different ways and to varied extents.

\subsection{Place-name preservation}

And so to name preservation or the reverse. An adopted place-name policy might argue for as few limitations and hindrances as possible for the existing repertoire of names and the unrestricted development of future name usages. It might deliberately advocate changes, new names and new naming patterns as valuable and creative - the use of names in step with modern society and its many and varied forms of expression. Streets and urban settings are refashioned, new patterns of movement emerge, buildings disappear and new ones are erected, the composition of populations change, businesses close and start up, etc. and place-name usages have to keep up in the same way and reflect these developments. This kind of policy would mean that names that feel out of date could be unsentimentally replaced by fresher ones.

In Sweden - in contrast to such an approach - place-name preservation has for a long time enjoyed great esteem (NILSSON et al. 2008). Officially determined place-names are not replaced nor are they changed unless there are very powerful reasons. Every change has to be examined and decisions are made in the stipulated fashion. We take into account the cultural and historical value of names whatever their age and we also make an assessment of the practical consequences of replacing or changing a name. Names are like annual rings in the landscape that tell us something about their eras. In this way placenames reflect our entire history and not just circumstances today. The current legislation on place-names - laid down in Section 4 of Chapter 1 of the Historic Environment Act 
(1988, p. 950, amended as 2013, p. 548) - is imbued with this place-name preservation approach and reads as follows:

"Good place-name practice

In state and local government operations, good place-name practice shall be observed. This means that

- place-names established by long usage shall not be changed without good cause,

- place-names shall be spelled in accordance with generally accepted rules for linguistic correctness, unless spelling forms established by long usage otherwise require,

- the impact on names established by long usage shall be taken into account when forming new place-names, and

- Swedish, Sami and Finnish names and names in Meänkieli shall, as far as possible, be used in parallel on maps and also for signs and other marking in multilingual areas.

- Names that have been approved by Lantmäteriet shall be used in the work of state and local government."

Well then, can the needs of modern society and its rapid changes be combined with a functional use of names and a desire to preserve place-names as part of our intangible cultural heritage? This is a pertinent question and the answer is a resounding yes - it is totally possible. A restrictive place-name policy that stresses the preservation and protection of place-names does not at all have to mean that the repertoire of names is conserved, only that it is not altered without reflection and consideration. We can introduce modern phenomena and new perspectives into our repertoires of names, for instance when there are unnamed objects that require names, rather than replace earlier place-names to make room for new ones.

To take another example from Stockholm, the city in which I live, in some areas we have taken new names for streets and blocks from the telecommunications industry and used words like modem, digital, telephone or names of individuals linked to developments of this kind. And we have done this when these areas have been developed or extended so that new names have been needed. We have not allowed new demands and wishes to result in the replacement and eradication of the footprints of history, but to supplement them. In these cases there are traces of different eras in the landscape of urban names. But if streets or squares disappear completely, then their names must at times be permitted to vanish, just as in rural environments when, for instance, farmland is reapportioned or virgin land reclaimed and used in new ways. A repertoire of names cannot be preserved at all costs neither in cities nor the countryside - but changes can be made prudently and respectfully.

\subsection{Place-name legislation}

A place-name policy can, therefore, be based on and find support in specific legislation or a policy's aim may be to bring about changes in the legislation. The official policy that applies in a specific society at any one time may be supported by explicit legislative or 
other legally binding documents. In Sweden - as we saw in Table 1 showed you earlier names of counties, municipalities and parishes are decided by the Swedish Parliament, the Government or the Diocesan Board as laid down in specific legal enactments. But on the other hand it has been a long-standing custom for municipalities to decide on the names of streets and squares in the detailed development plans for certain urban areas. There are no statutes or instructions that stipulate this. But when it comes to the form taken by a name, its spelling and how it is otherwise dealt with, both state authorities and municipalities have to comply with the paragraph on good place-name practice in the Historic Environment Act.

Where Sweden is concerned the place-name policy has not been changed to any great extent since the enactment of specific legal provisions on place-names in 2000 - we have a long tradition of name preservation, regulations about names and other aspects of their management in Sweden - but the statutes from 2000 still provide sound support in arguments and discussions and give more weight to issues relating to names in society. An evaluation of the effects of the legislation on the actions of the municipalities (KarLSSON and NySTRÖм 2006; NYSTRÖм 2013, p. 129) contained the following observation:

"The answers and comments from the municipalities also showed that the addition of the place-name paragraph had not resulted in any significant changes in the way the work is organised when handling place-name affairs. But many of them emphasised that - and this is an important result - due to the Act there is an obvious increase of interest, of awareness and of consideration, especially concerning the preservation and management of place-names as parts of the intangible cultural heritage, but also concerning place-names as necessary linguistic expressions for daily use (including their morphology and spelling). People handling place-name affairs in the municipalities actually felt a bit more appreciated and respected after the introduction of the name paragraph."

The decision to include place-names in the legislation enhances, in other words, the value and significance of place-names in discussions, puts a focus on place-name issues and means that flagrant abuse of the right to determine and to manage names has become less frequent. This is a good thing! Awareness of the statutory provisions provides a basis for greater possibilities of coordinating the ways in which different authorities and bodies decide on names as it is easier to produce a shared norm - a benchmark - that can be circulated to serve as an example to others.

\section{Tasks and challenges?}

What then are the major tasks and challenges for rational place-name policies today? Well, there are of course a large number of widely varying challenges if we adopt a global perspective and I can only mention a few here that are important in my part of the world:

- It is important to lay down who makes decisions, what kinds of names they decide on and on what grounds; who is entitled to express an opinion about names of this kind 
and who has the right to appeal against a decision to adopt a name. If there are no regulations about this they should be introduced as soon as possible.

- There are many stakeholders with different powers and different messages to convey. It is important to find ways and methods to reach them and provide them with information so that all right-minded contributors move in the same direction.

- It is important to counter the commercialisation of the repertoire of names. Here we can invoke, for instance, a UN resolution. Economic forces can easily run counter to cultural historical and practical concerns. Are the names Metallatervinning Arena ['Metal Recycling Arena'] and Tele2 Arena good ones? They both include names of business companies. Will they still exist in five years if new sponsors take over?

- The increasing anglicisation of the repertoire of names (or other linguistic influences linked to prestige and status) has to be confronted: Stockholm Waterfront Conference Centre, Ericsson Globe Arena, etc. These are the names of venues (and therefore relatively manageable) but demands have been made in the capital of Sweden for English names for Metro stations, parks and hospitals. Is this good and who is it good for?

- Contacts between languages (apart from English) also have to be dealt with. To what extent can settings in which two or more languages are used be reflected in placename usage. These settings can be historical and long-standing or they may have arisen recently as a result of immigration. How can we deal with the complicated issue of minority languages and the revitalisation of place-names?

Although I have not said a great deal about this in this paper, the wording of the Swedish statutes makes it clear that the official management of names must include parallel Sami or Finnish names as well as names in Meänkieli in areas where established names in these languages exist. No name has to be translated to a minority language today or be created anew in these languages. Revitalisation of minority language names in Sweden involves therefore cataloguing the names that exist and then ensuring their use in official contexts. A place-name policy can, however, opt to go further than this in its endeavours to promote minority languages. Extensive programs on this have been launched in for instance Australia, Canada, and New Zealand.

In Sweden other major languages, such as Arabic, Kurdish, Turkish, Spanish, Persian, Serbian, Croatian, Bosnian or Somali, that are spoken in certain areas with large immigrant populations in the large cities, have not yet left any direct traces in official placename usage. Varying forms of Swedish seem to function as a lingua franca where the use of names is concerned as well.

\section{What contributions can place-name researchers make?}

Finally the question arises of how place-name research and place-name scholars can contribute to understanding and awareness about these important aspects of place-names and how they are determined?

Universities and other institutions must include place-name planning, place-name standardisation and place-name preservation in the teaching and research they offer about 
place-names. Individual researchers can act to make this possible. Lots of useful material is available on the UNGEGN website.

Researchers should, as far as possible, contribute through popular lectures, articles, radio broadcasts etc. in different contexts to making sure that sensible ideas about placenames as well as knowledge and insights into naming and place-name standardisation are made available to the general public and decision-makers in different positions.

Researchers should endeavour to take part in serious collaboration in networks and work groups with participants from a variety of organisations, institutions and authorities outside the academic world. Two examples from Sweden that I can mention are the PlaceName Advisory Board and the Geographical Names Network. The first group includes members from Lantmäteriet, the National Heritage Board, the Institute for Language and Folklore, the Swedish Universities, the Swedish Association of Local Authorities and Regions, the Swedish Transport Administration, and the Sami Parliament, while the second consists of representatives from Lantmäteriet, the Ministry for Foreign Affairs, the Institute for Language and Folklore, including the Language Council of Sweden, the University of Uppsala, the Swedish Centre for Terminology, Radio Sweden, the Swedish Standards Institute, the Swedish Translation Service in the General Secretariat of the EU Council and the Institute for the Languages of Finland. Both these groups provide information and advice to other name stakeholders in society while at the same time they learn a lot from each other.

\section{In conclusion}

So to conclude: discussion of place-name policies covers a very wide field and this is a subject that can involve a large number of considerations. I have tried to shed light on some aspects on the basis of my own experience of working with these policies at various levels. I hope that I have at least been able to provide some inspiration for others to continue to work in this important area. Place-name policies and place-name standardisation are important aspects of place-name research, aspects that have a direct impact on a large number of people.

\section{References}

Gammeltoft P. (2016): The Danish Place-Name Commission. In: UNGEGN Information Bulletin, 51, pp. 11-12.

KARLSSON J., NySTRÖM S. (2006): God ortnamnssed i kommunerna. En enkätundersökning kring den kommunala ortnamnsverksamheten i förhållande till paragrafen om ortnamn i kulturminneslagen [Good place-name practice in the municipalities. An inquiry concerning local place-name activities as regards the place-name paragraph in the Historic Environment Act]. Stockholm: Riksantikvarieämbetet (= Rapport från Riksantikvarieämbetet, 2006:5).

Nilsson L., Nyström S., Torensuö A. (2008): Swedish Place-name Legislation and its Emphasis on the Preservation of Geographical Names as a Part of the Nation's Cultural Heritage. In: Jordan P., Bergmann H., Cheetham C., Hausner I. (eds.): Geographical Names as a Part 
of the Cultural Heritage. Vienna, Institut für Geographie und Regionalforschung der Universität Wien, pp. 59-63 (= Wiener Schriften zur Geographie und Kartographie, 18).

Nyström S. (2013): Commemorative Naming - Possibilities and Problems. In: ArCamone M. G., Bremer D., De CAmilli D. et al. (eds.): Atti del XXII Congresso Internazionale di Scienze Onomastiche. Pisa, 28 agosto -4 settembre 2005. Vol. 5. Pisa, pp. 723-732.

Nyström S. (2015): Swedish Place-name Legislation: Application, Evaluation, Revision. In: Onoma. Journal of the International Council of Onomastic Sciences, 47 (2012), pp. 119-136.

Nyström S., NiLSSON L., ToREnsJö A. (2016): God ortnamnssed. Ortnamnsrådets handledning i namnvård [Good place-name practice. A guide to name standardisation]. Andra reviderade upplagan [Second revised edition]. Gävle: Lantmäteriet (= Ortnamn och namnvård, 6. Lantmäteri-rapport, 2016:9).

ToRENSJö A. (2015): Ortnamnsinsamling igår och idag. Ny teknik, nya metoder? [New methods of field collection of place-names]. In: ALdRIn E., GuSTAFSOn L., LöFdAHL M., WenNER L. (eds.): Innovationer i Namn och namnmönster [Innovations in names and name patterns]. Handlingar från NORNA:s 43:e symposium i Halmstad den 6-8 november 2013. Uppsala, NORNA-förlaget, pp. 283-290 (= NORNA-rapporter, 92). 